\title{
In silico and in situ characterization of the zebrafish (Danio rerio) gnrh3 (sGnRH) gene Jacob Torgersen ${ }^{* 1}$, Rasoul Nourizadeh-Lillabadi ${ }^{1}$, Harald Husebye ${ }^{2}$ and Peter Aleström ${ }^{1}$
}

Address: ${ }^{1}$ Department of Biochemistry, Physiology and Nutrition, Norwegian School of Veterinary Science, PO Box 8146 Dep., N-0033 Oslo, Norway and ${ }^{2}$ Department of Botany, NTNU/ Realfagbygget, N-7491 Trondheim, Norway

E-mail: Jacob Torgersen* - jacob.torgersen@veths.no; Rasoul Nourizadeh-Lillabadi - bfelilla@veths.no;

Harald Husebye - harald.husebye@ chembio.ntnu.no; Peter Aleström - peter.alestrom@veths.no

${ }^{*}$ Corresponding author

This article is available from: http://www.biomedcentral.com//47/-2/64/3/25

(C) 2002 Torgersen et al; licensee BioMed Central Ltd. This article is published in Open Access: verbatim copying and redistribution of this article are permitted in all media for any non-commercial purpose, provided this notice is preserved along with the article's original URL.

\begin{abstract}
Background: Gonadotropin releasing hormone $(\mathrm{GnRH})$ is responsible for stimulation of gonadotropic hormone $(\mathrm{GtH})$ in the hypothalamus-pituitary-gonadal axis (HPG). The regulatory mechanisms responsible for brain specificity make the promoter attractive for in silico analysis and reporter gene studies in zebrafish (Danio rerio).

Results: We have characterized a zebrafish $\left[\operatorname{Trp}^{7}\right.$, Leu $\left.{ }^{8}\right]$ or salmon (s) GnRH variant, gnrh3. The gene includes a $1.6 \mathrm{~Kb}$ upstream regulatory region and displays the conserved structure of 4 exons and 3 introns, as seen in other species. An in silico defined enhancer at -976 in the zebrafish promoter, containing adjacent binding sites for Oct-I, CREB and SpI, was predicted in 2 mammalian and 5 teleost $\mathrm{GnRH}$ promoters. Reporter gene studies confirmed the importance of this enhancer for cell specific expression in zebrafish. Interestingly the promoter of human GnRHI, known as mammalian $\mathrm{GnRH}(\mathrm{mGnRH})$, was shown capable of driving cell specific reporter gene expression in transgenic zebrafish.

Conclusions: The characterized zebrafish Gnrh3 decapeptide exhibits complete homology to the Atlantic salmon (Salmo salar) GnRH-III variant. In silico analysis of mammalian and teleost GnRH promoters revealed a conserved enhancer possessing binding sites for Oct-I, CREB and SpI. Transgenic and transient reporter gene expression in zebrafish larvae, confirmed the importance of the in silico defined zebrafish enhancer at -976. The capability of the human GnRH-I promoter of directing cell specific reporter gene expression in zebrafish supports orthology between $\mathrm{GnRH}-\mathrm{I}$ and $\mathrm{GnRH}-\mathrm{III}$.
\end{abstract}

\section{Background}

Gonadotropin releasing hormone $(\mathrm{GnRH})$ controls reproduction in vertebrates through the HPG axis [1-3]. In fish, the GnRH synthesizing neurons innervates the pituitary gland [4-6], and upon binding of GnRH to the recep- tor, GtH production is stimulated. This receptor mediated signal transduction pathway stimulates gonadal maturation, gametogenesis and production of sex steroids, which impose feedback on the HPG axis [7-12]. The evolutionary conserved GnRH decapeptide has been characterized 


\begin{tabular}{|c|c|c|c|c|}
\hline Zebrafish & sGnRH & (Danio rerio) & Gnrh3 & QHWSYGWLPG \\
\hline Atlantic salmon & sGnRH & (Salmo salar) & GnRH-III & QHWSYGWLPG \\
\hline Sea lamprey & 1GnRH-III & (Petromyzon marinus) & GnRH-? & QHWSHDWKPG \\
\hline Chicken & cGnRH-II & (Gallus gallus) & GnRH-II & QHWS HGWYPG \\
\hline Tunicate & tGnRH-II & (Chelyosoma productum) & GnRH-? & QHWSLCHAPG \\
\hline Human & $\mathrm{mGnRH}$ & (Homo sapiens) & GnRH-I & QHWSYGLRPG \\
\hline Gilt head seabream & sbGnRH & (Sparus aurata) & GnRH-I & QHWSYGLSPG \\
\hline Chicken & cGnRH-I & (Gallus gallus) & GnRH-I & QHWSYGLQPG \\
\hline Herring & hrGnRH & (Clupea harengus pallasi) & GnRH-? & QHWSHGLSPG \\
\hline African catfish & cfGnRH & (Clarias gariepinus) & GnRH-I & QHWSHGLNPG \\
\hline Spiny dogfish & dfGnRH & (Squalus acanthias) & GnRH-? & QHWSHGWLPG \\
\hline Guinea pig & gpGnRH & (Cavia porcellus) & GnRH-I & QYWSYGVRPG \\
\hline Tunicate & tGnRH-I & (Chelyosoma productum) & GnRH-? & QHWSDYFKPG \\
\hline Sea lamprey & 1GnRH-I & (Petromyzon marinus) & GnRH-? & QHYSLQWKPG \\
\hline Pejerry & pjGnRH & (Odontesthes bonariensis) & GnRH-? & QHWSFGLSPG \\
\hline Dybowski's Brown Frog & {$\left[\operatorname{Trp}^{8}\right] \mathrm{GnRH}$} & (Rana dybowskii) & GnRH-? & QHWSYGLWPG \\
\hline Common octopus & GnRH-like & (Octopus vulgaris) & GnRH-like & QNYHFSNGWHPG \\
\hline
\end{tabular}

Figure I

GnRH decapeptide conservation Sequence comparison of mature GnRH peptides [13-I5], show complete similarity between Atlantic salmon GnRH-III and zebrafish Gnrh3. The common name, species of origin nomenclature, scientific name, GnRH-I, -II or -III nomenclature and corresponding mature $\mathrm{GnRH}$ peptides are shown.

directly or indirectly in a number of vertebrates and a few invertebrates and currently includes 15 different decapeptide variants $[13,14]$, though if the common octopus $(O c$ topus vulgaris) GnRH-like mature peptide (dodecapeptide) is included, a total of 16 variants have been characterized till day [15] (Fig. 1). The variants are commonly named according to species of origin, but may also be named GnRH-I, -II or -III, based on sequence alignments solely [16] (Fig. 1). The GnRH expression pattern in the brain of fish has revealed segregation into a posterior and anterior system [6], where the former exhibits the releasing variants and the latter GnRH-II, also known as chicken GnRH-II (cGnRH-II) [4,17-19]. Differential expression of three GnRH forms was initially shown in the brain of the gilthead sea bream (Sparus aurata) [20], and more recently in African cichlid (Haplochromis burtoni) and the ancient herring (Clupea harengus pallasi) [21-23]. In the European sea bass (Dicentrarchus labrax), GnRH-I and GnRH-III, also known as the sea bream (sbGnRH) and salmon (sGn$\mathrm{RH}$ ) variants, have been found co-expressed in the olfactory bulbs, ventral telencephalon and preoptic region and ventral thalamus, with a bias towards stronger GnRH-I activity in the preoptic area, compared to GnRH-III [24]. Expression and in situ data from the African cichlid have demonstrated presence of GnRH-I (sbGnRH) in the preoptic area and GnRH-III (sGnRH) in the areas of the ter- minal nerve and pituitary, suggesting GnRH-I to be the releasing form [25-27]. The genomic structure of GnRH is highly conserved, and comprises 4 exons and 3 introns $[28,29]$. The 5 ' untranslated region (UTR) is encoded by exon I, whereas the signal peptide, GnRH decapeptide, proteolytic cleavage site (GKR) and the N-terminus of the GnRH associated peptide (GAP) are encoded by exon II. Exon III encodes the mid section of GAP and exon IV encodes the GAP C-terminus and the 3' UTR.

The gene product of zebrafish gnrh3 has previously been detected by use of HPLC and RIA [30], and here we describe the cDNA and gene, including upstream sequence. Since the sGnRH variant is classified as GnRH-III [16], we propose to name the characterized zebrafish gene gnrh3 and the product Gnrh3, according to the zebrafish nomenclature convention [http://zfin.org/zf_info/nomen.html]. Zebrafish genes use lowercase and italics and the gene products are given a first capital letter and the remaining in lower case non-italics. For non-zebrafish genes and proteins we use GnRH-I, -II or -III nomenclature [16]. The upstream region of zebrafish gnrh 3 has been analyzed with a set of bioinformatic tools and we show experimentally that in silico predicted transcription factor (TF) elements are involved in tissue specific expression in the forebrain. We also report tissue specific control of tran- 


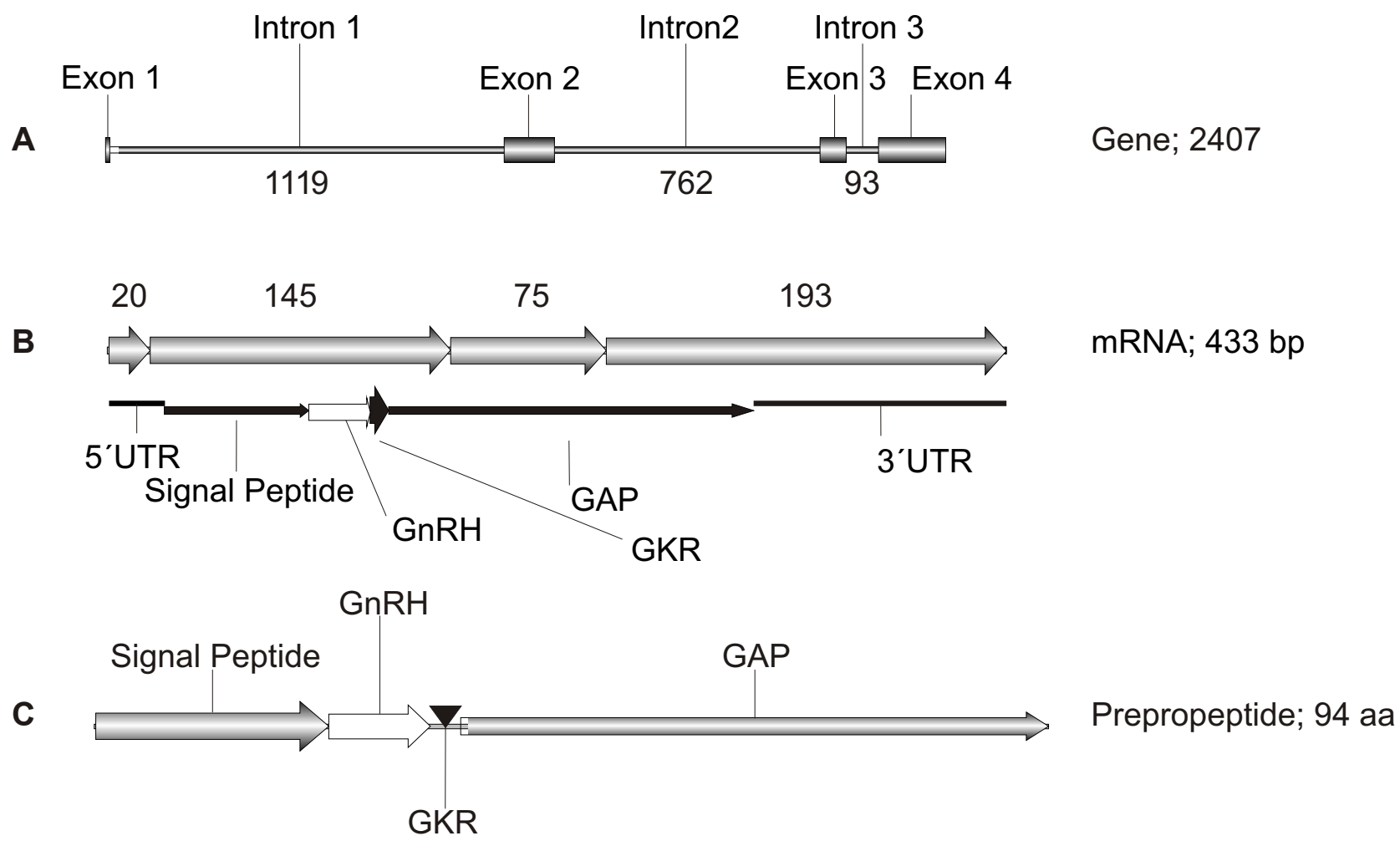

Figure 2

A) Schematic intron-exon diagram of the zebrafish gnrh 3 gene The exons and introns are marked as boxes and lines, respectively. The intron lengths are shown underneath the lines. B) Exon lengths are shown above the mRNA sequence. The functional domains of the prepro polypeptide and untranslated regions (UTR) are marked. C) Post-translational cleavage of the signal peptide and GAP at the proteolytic cleavage site (GKR), generate the mature Gnrh3 decapeptide from the prepro polypeptide.

scription, conserved between zebrafish and man, using the human GnRH-I promoter for driving cell specific expression in transgenic zebrafish.

\section{Results}

\section{Zebrafish gnrh3 gene}

Zebrafish cDNA was cloned from poly A selected RNA using PCR primers complementary to the conserved GnRHIII decapeptide and GAP mRNA regions. Contig assembly of 5' and 3' RACE (rapid amplification of cDNA ends) clones resulted in a 433 bp long cDNA, featuring a 282 bp open reading frame (ORF) with 5' and 3' UTR of 27 and 124 bp. BLAST analysis of the prepro polypeptide and multiple sequence alignment of the decapeptide resulted in a high score of $10^{-34}$ to the Roach (Rutilus rutilus) prepro GnRH-III [31] and complete homology to the Atlantic salmon GnRH-III [29], respectively (Fig. 1). The 94 aa prepro polypeptide consists of a 23 aa signal peptide, GnRH decapeptide, proteolytic cleavage site (GKR) and 58 aa GAP (Fig. 2). The proteolytic cleavage site is conserved in all GnRH genes analyzed to date, whereas the signal peptide and GAP domains exhibit conservation of low scoring patterns (data not shown).

\section{Zebrafish gnrh3 promoter sequence}

The PCR promoter capture strategy (Fig. 3) resulted in 1656 bp upstream of the transcription start site (TSS) determined by 5 ' RACE. Analysis of the zebrafish exon I and 5 ' flanking sequence using Neural Network Promoter Prediction, revealed 4 putative TSS, hence Pol II promoters at $-7,-114,-1156$ and -1406 , with corresponding scores of $0.85,0.95,0.98$ and 0.92 . Verification of TSS with Promoter Scan II failed, as no Pol II promoters were recognized with this software.

High sensitivity Repeat Masker analysis of the zebrafish gnrh3 promoter demonstrated $75 \%$ similarity to a $340 \mathrm{bp}$ DANA-SINE element [32] and a 21 bp low complexity region at -1208 and -831 , respectively. An incomplete $81 \mathrm{bp}$ TOL2 transposable element motif [33] was registered at - 
A)

B)

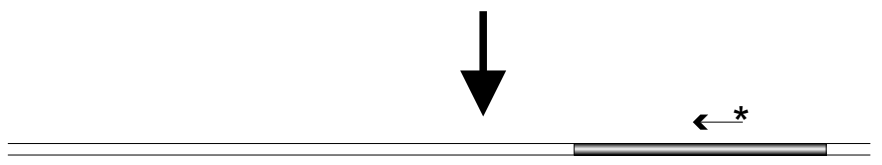

Sheared DNA 4-10 Kb

\section{Asymetrical PCR}

\section{Purification with magnetic beads}

C)

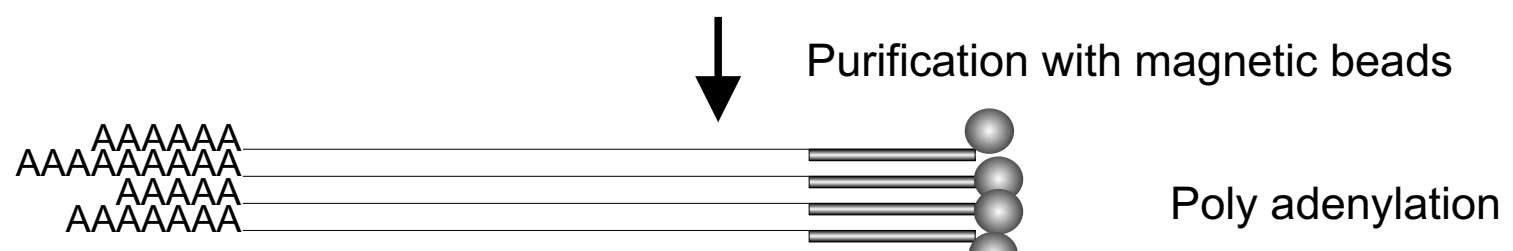

$\downarrow$ Purification with magnetic beads

D)

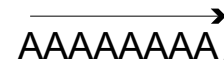

$\leftarrow$

Nested PCR

\section{Figure 3}

Overview of the PCR promoter capture method A) Sheared genomic DNA of 4-10 Kb harboring the gene of interest (thick line) is used as template in B) asymmetrical PCR reactions. The reactions are conducted with a biotinylated high Tm antisense primer and $C$ ) the resulting single stranded fragments are purified with streptavidin coated magnetic particles. D) A secondary PCR reaction is conducted with an oligo $\mathrm{dT}_{20}$ and a nested anti-sense primer.

570 with $72 \%$ similarity. Optimization of the transcription factor binding tools revealed that both TESS and Matinspector, using default parameters, correctly predicted the previously described -1501 , but not the -1569 estrogen receptor (ERE) motif in the Atlantic salmon GnRH-III upstream promoter $(\mathrm{Pa})[34]$. Less stringent conditions resulted in an increased number of false positive ERE binding sites. Analysis of the Atlantic salmon Pa promoter using AliBaba 2.1, showed correct prediction of both ERE motifs with the default set up and was used for analysis of the Atlantic salmon GnRH-III Pa and downstream $(\mathrm{Pb})$ promoter [29], human GnRH-I upstream [35] and downstream [36], striped bass (Morone saxatilis) GnRH-I [37], rat (Rattus norwegicus) GnRH-I [38], and African cichlid GnRH-I and GnRH-III promoters [22], using optimized and decreased stringency when necessary. Transcription factors experimentally shown to be involved in the regulation of GnRH expression, or to possess binding affinity to the promoter, include the POU factors Oct- 1 and Oct$6[39,40]$, ERE $[7,8,34,41-43]$, glucocorticoid receptor (GR) [44], progesterone receptor (PR) [8,45,46], GATA-1 $[47,48]$, cyclic AMP responsive element binding protein (CREB) [49], SF-1 [50] and Otx2 [51]. In silico predicted TF binding sites include Ap-1, ERE, GHF-2, GH-CSE2 and Pit-1 in Pacific salmon (Oncorhynchus nerka) [52], Ap-1, GR, PR, and Sp1 in African cichlid [22], Ap-1, CREB, ERE, GATA, GR, and Oct-1 in masu salmon (Oncorhynchus masou) [53], and members of the POU family, Ap-1, Brn-2, CREB, ERE, GR, Pit-1, and SF-1 in striped bass [37]. Of the above listed TF's, no putative binding sites could be predicted for SF-1, Brn-2, Oct- 6 and Otx2 in either of the promoters. No obvious frequencies or patterns could be detected with respect to the binding sites of ERE, PR, GR, GATA-1, AP-1, Sp1, Pit-1 and Oct-1, as they were found abundantly in all promoters, with the exception of the salmon Pa and human downstream promoter, which 


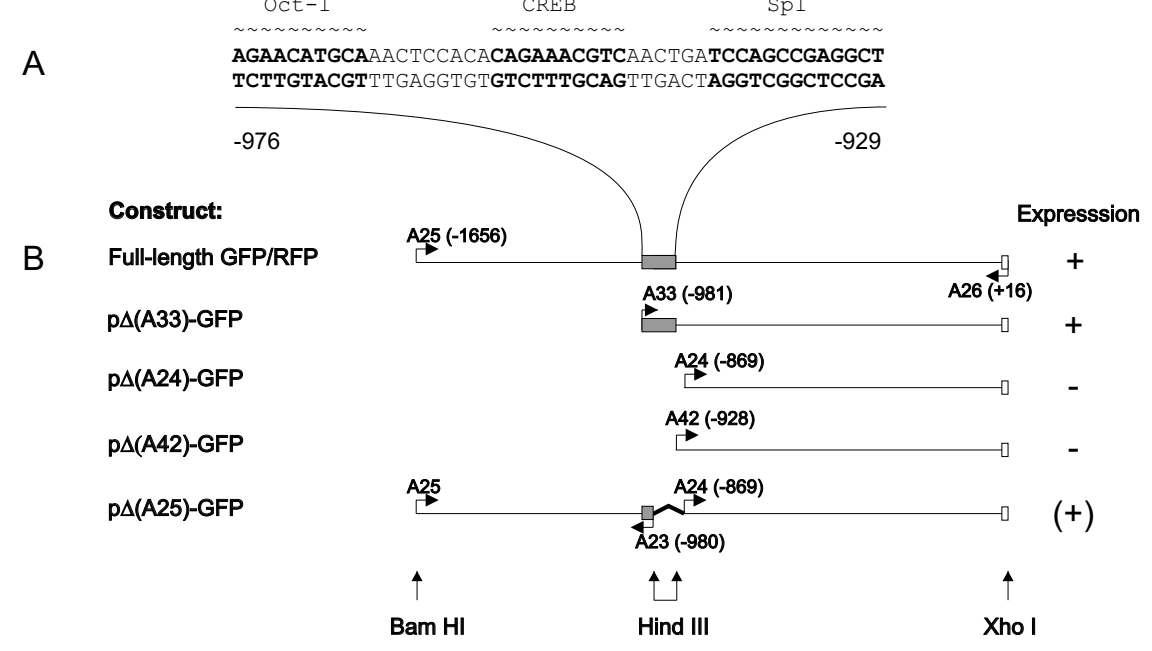

C

Zebrafish gnrh3 Human downstream GnRH-I African cichlid GnRH-I African cichlid GnRH-II African cichlid GnRH-III
Atlantic salmon $\mathrm{Pb}$ GnRH-II Striped bass GnRH-I Rat GnRH-I

\begin{tabular}{llclcll} 
Coord. & Elem. & Space & Elem. & Space & Elem. & Coord \\
\hline-976 & Oct-1 & 9 & CREB & 6 & Sp1 & -929 \\
-446 & Oct-1 & 10 & Sp1 & 6 & CREB & -395 \\
-1106 & Oct-1 & 16 & CREB & 2 & Sp1 & -1153 \\
-183 & Oct-1 & 11 & CREB & 11 & Sp1 & -122 \\
-152 & Oct-1 & 16 & CREB & 33 & Sp1 & -74 \\
-459 & Oct-1 & -- & CREB & -- & --- & -477 \\
-1622 & Oct-1 & 9 & CREB & 14 & Sp1 & -1570
\end{tabular}

D
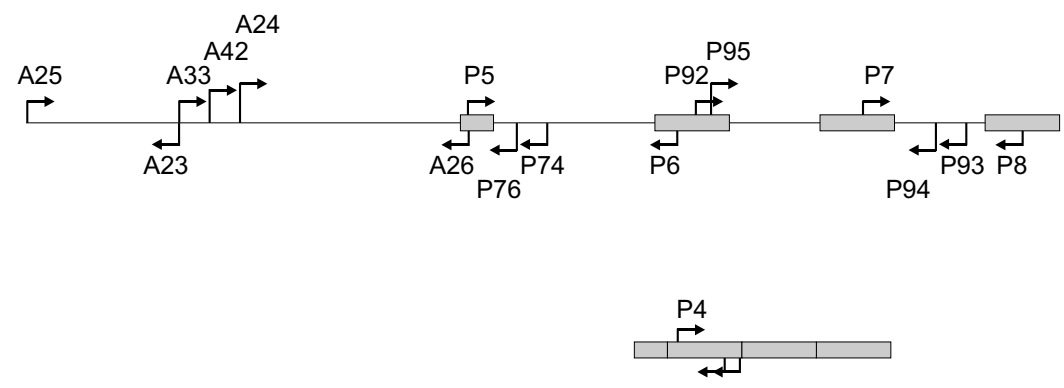

$\mathrm{P} 1$

$P 2$

\section{Figure 4}

GnRH tissue specific enhancer and promoter constructs A) The in silico predicted zebrafish gnrh3 enhancer region located between -976 and -929 , featuring binding sites for Oct-I, CREB and Spl. Coordinates are negatively numbered with the experimental TSS as +I. B) Schematic overview of all zebrafish constructs tested, with nomenclature by sense primer used. The human RFP construct is not shown. The 9l bp deletion (-960 to -869) in the $p \Delta(A 25)$-GFP is denoted by an angle in the thin line. The gray and the white boxes correspond to the enhancer and exon I, respectively. Arrows describe PCR primers, showing name and distance from the upstream end relative to TSS. Restriction sites at the bottom correspond to the tail of the PCR primers used for amplification of alternative promoter fragments. Transient expression data are indicated with,+- or $(+)$, the latter denoting broader cell specificity. PCR primer sequences: A23 (5'aagcttggagtttgcatgttctccct3'), A24 (5'aagcttcctttcttaaaatattgaattatgat $\left.3^{\prime}\right), \quad$ A25 (5'ggatcccttcagggatgccaggtctt3'), A26 (5'ctcgaggctgtgtttgttcaagatgagttct $\left.3^{\prime}\right), \quad$ A33 (5'aagcttcagggagaacatgcaaact 3 ') and A42 (5'aagcttggaatcagagaccttcttgct3'). C) The putative enhancer featuring binding sites for Oct-I, CREB and Spl is $100 \%$ conserved with respect to presence of Oct-I and CREB for the promoters tested [22,29,3638]. The distance to TSS $(+1)$, the transcription factor binding site and number of nucleotides between binding sites (space), are shown for each promoter. The location of the predicted enhancer in rat GnRH-I is according to data published [54]. D) Schematic overview of primer binding sites and the orientation of the respective primers. The upper line denotes genomic DNA and the lower mRNA, where both are displayed in 5'-3' direction. Exons are shown as gray boxes and primers as arrows. 
lacked Sp1 and Pit-1 motifs, respectively. Binding sites for CREB were predicted in all brain specific promoters tested, whereas the Atlantic salmon $\mathrm{Pa}$ and the gonad specific human upstream promoter lacked the motif. An additional CREB motif was also detected at -878 in the zebrafish promoter. Interestingly, single Oct-1 and Sp1 binding sites were found adjacent to the CREB motif at -957 in the zebrafish promoter (Fig. 4a). Based on this information, one reporter gene vector exhibiting the predicted enhancer $[\mathrm{p} \Delta$ (A33)-GFP], another lacking the predicted enhancer [p $\Delta$ (A42)-GFP], and a third lacking the -878 CREB motif and upstream sequence $[\mathrm{p} \Delta(\mathrm{A} 24)-\mathrm{GFP}]$ were constructed and tested for capability of driving reporter gene expression. As a result of the observed expression or lack thereof (see below), the remaining promoter sequences were analyzed for presence of these three binding sites in cluster, with more weighting of Oct- 1 and CREB. The African cichlid GnRH-I and Atlantic salmon Pb GnRH-III promoters described the three motifs at $75 \%$ min. matrix conservation, whereas striped bass GnRH-I lacked the Sp1 binding site. Stringency had to be decreased to $70 \%$ for detection in the rat and human downstream GnRH-I, and African cichlid GnRH-III promoters (Fig. 4c). In the GnRH-I promoter of rat, an additional Oct-1 / CREB dimeric binding site with 13 nt spacing was predicted between -1159 and 1127 , using $70 \%$ min. matrix conservation. The location of the predicted motifs and the brain specific rat enhancer are relative to TSS [54].

\section{Reporter gene expression}

The full-length zebrafish gnrh3 promoter construct expressed GFP in $10 \%$ and $30 \%$ of microinjected embryos at 3 and 4 days post fertilization, respectively (Fig. 5). In all cases the reporter gene activity was located to cells in the areas of olfactory bulb and telencephalon, featuring short protruding axons. A number of reporter gene constructs with alternative promoter deletions were created and named according to the sense PCR primer used (Fig. 4). The $\mathrm{p} \Delta$ (A33)-GFP construct possessing the complete in silico defined enhancer, was found to be capable of driving forebrain specific expression, with a similar pattern of expression as for the full-length construct. Both $\mathrm{p} \Delta$ (A24)GFP and $\mathrm{p} \Delta$ (A42)-GFP had the enhancer region deleted and revealed however no reporter gene activity, whereas $\mathrm{p} \Delta$ (A25)-GFP possessed forebrain activity in $6 \%$ of the larvae at 4 days post fertilization (p.f.). The latter construct possessed deleted CREB and Sp1 motifs. A discrepancy in cell specificity, between the full-length and $\mathrm{p} \Delta(\mathrm{A} 25)$-GFP construct was observed, the latter showing broader cell specificity and revealed green fluorescent protein (GFP) activity in other neural cells in the mid and hindbrain area (Fig. 5). To examine the discrepancy further, a co injection with full-length RFP and $\mathrm{p} \Delta(\mathrm{A} 25)$-GFP was conducted. The resulting expression pattern consisted of co-localized GFP and red fluorescent protein (RFP) activity in the fore- brain of some, but not all individuals (fig. 5). Transient expression data from the human GnRH construct showed RFP activity in $2 \%$ of the larvae at day 7 p.f. and transgenic offspring (F1 generation) harboring the full-length zebrafish or human promoters, possessed GFP and RFP activity in the exact same cell population in the area of olfactory bulb and telencephalon at 5 days p.f. (Fig. 5). Laser confocal microscopy of full-length GFP transgenic F1 larvae at 5 days post fertilization, revealed similar location and morphology of the GFP expressing cells, as observed transiently (data not shown).

\section{Discussion}

The nearly finalized genome project and importance as a model in vertebrate developmental biology, renders increased value for zebrafish as a model in functional genomics. We have chosen the zebrafish gnrh3 promoter to compare three tools for prediction of transcription factor binding sites and investigate factors involved in tissue specificity of zebrafish gnrh3. The genomic organization with four exons and three introns, confirms the overall conserved structure of GnRH genes previously characterized $[28,55]$. In the analysis for alternative Pol II promoters and TSS in the sequence upstream of exon I, only Neural Network Promoter Prediction recognized promoter elements in the $1.6 \mathrm{~kb}$ sequence upstream of the gene and thus confirmed the TSS from our experimental 5' RACE data, although with a discrepancy of $7 \mathrm{nt}$. Three additional TSS were predicted, of which the high scoring putative Pol II promoter at -1156 would resemble the putative Pa promoter in Atlantic salmon located upstream of exon Ia at 1247 , relative to the TSS of the proximal promoter $\mathrm{Pb}$ [29]. Since our data are based on mRNA extracted from brain, we have no experimental data on alternative promoter activity in the gonads, as observed with human GnRH-I [35].

Regarding prediction of regulatory elements involved in tissue specific control of the zebrafish gnrh 3 promoter, a number of bioinformatic tools are available [56]. Briefly they recognize putative binding sites by use of IUPAC consensus (TESS filtered) (Schug J, Overton CG [http:// www.cbil.upenn.edu/tess/index.html]), context (AliBaba 2.1) [57], or transcription factor binding site matrix information (Matinspector) [58]. Alternatively, Hidden Markov Model (HMM) and other algorithms for pattern recognition may be used. Currently the context-based method seems to be the most specific alternative for TF binding site analysis [57], as also confirmed by our comparative in silico analysis of the ERE motifs in the salmon GnRH-III Pa promoter [34]. Of importance when predicting TF binding sites is sensitivity and specificity, since too low specificity will bury correct motifs in a wealth of false positives, hindering correct interpretation of the data. Transcriptional response to cellular signals is frequently 
Full-length promoters

A Transient expression

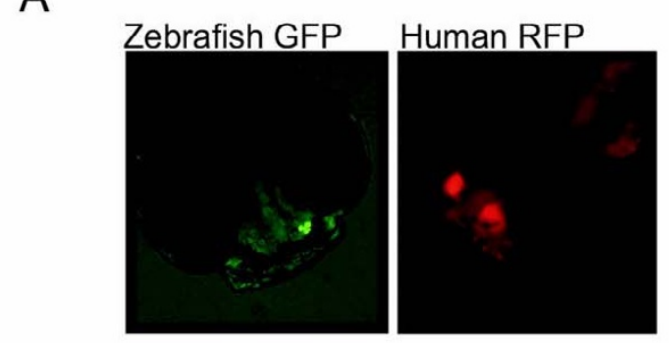

Full-length promoters

B Transgenic expression

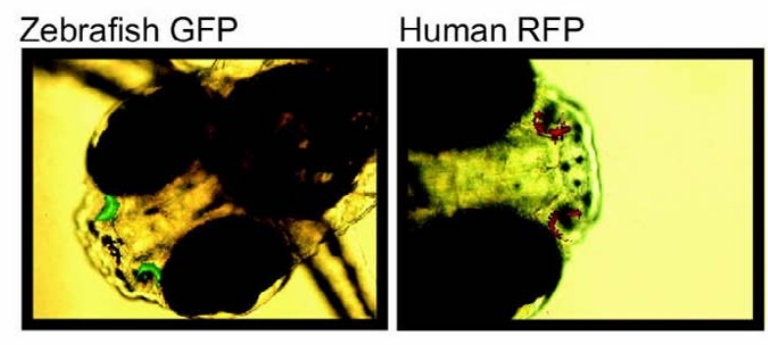

C

Transient expression

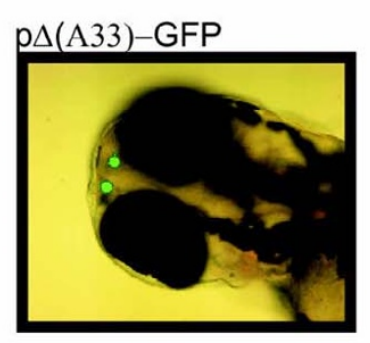

Transient expression

$\mathrm{p} \Delta$ (A25)-GFP plus full-length RFP
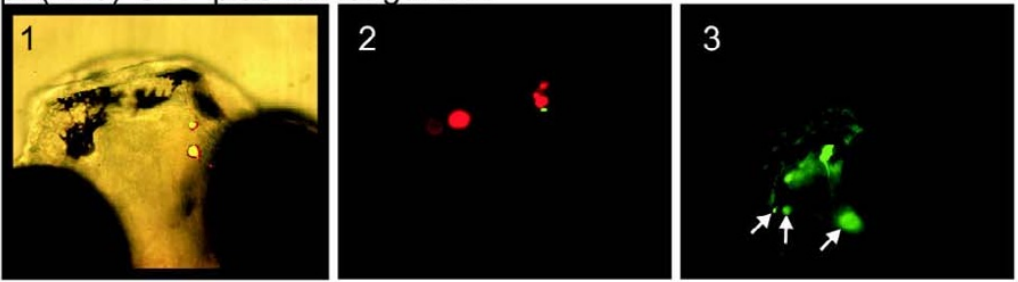

\section{Figure 5}

Reporter gene expression A) Transient GFP and RFP expression driven by the full-length zebrafish and human promoters. B) Zebrafish and human full-length -GFP and -RFP transgenics (FI) show reporter gene activity in the same cells. C) Retained cell specificity of $\mathrm{p} \Delta(\mathrm{A} 33)$-GFP. D) Expression patterns of $\mathrm{p} \Delta(\mathrm{A} 25)$-GFP. (I) Co-localized GFP and RFP activity (yellow) of $\mathrm{p} \Delta$ (A25)-GFP and full length RFP. (2) Some of the co-injected larvae displayed broader cell specificity and lack of co-localization. (3) GFP activity in midbrain/hindbrain located neuronal cells (arrows). 
mediated through co-operation between transcription factors binding to neighboring binding sites. The maximum or minimum distance between two co-operative sites/half sites are of importance, but as bending of DNA may bring two distant TF binding sites into vicinity, we have chosen to look for binding sites with up to $30 \mathrm{bp}$ spacing. Two new bioinformatic tools have been developed to cope with factors interacting over longer distances, CISTER [59] and FastM [60], but as their sensitivity and specificity seems inferior to AliBaba, we chose not to use them. Certain TF's may contribute to the basal activity of a promoter being responsible for tissue specificity, whereas others modulate the level of expression. So far most studies investigating GnRH-I or GnRH-II promoter regulation have been conducted in mammalian systems [7,8,39-51]. It has been postulated that GnRH-III has replaced the GnRH-I variant as a result of mutations [23]. This also implies that the transcription factors involved should be conserved between the corresponding promoters. The reason why we could not predict binding sites for SF-1, Brn-2, Oct-6 and Otx-2, may be due to lack of SF-1 and Otx-2 matrix information in the TRANSFAC database (db) [61], used by AliBaba 2.1. A high stringency search for these factors using TESS revealed no consensus among the promoters, with respect to SF-1 and Otx-2. The matrix information for Brn-2 is sufficient in the TRANSFAC db, and the absence of this factor from the AliBaba predictions was judged reliable or false negative. Binding sites for the remaining TF's mentioned also revealed lack of consensus with the exception of CREB. This shows the complexity of GnRH regulation, as many transcription factors have been shown to be involved in tissue specificity and modulation of expression. The findings of CREB motifs in all GnRH promoters analyzed indicate that this factor may be responsible for the tissue specificity, even though we had to decrease the stringency for detection in the rat GnRH-I enhancer, human downstream GnRH-I and African cichlid GnRH-III promoters. Decreased search stringency may lead to false positives, but by including the proximate Oct- 1 binding site and searching the upstream Atlantic salmon and human promoters at low stringency, without finding any adjacent CREB and Oct-1 motifs, we believe that the in silico predictions are reliable. Our findings are also supported by observation of altered expression when the human downstream promoter is truncated to -350 [36], as the putative enhancer is located between 445 and -397 . Truncation of the rat enhancer from -1863/ -1571 to $-1863 /-1636$ has been shown to reduce expression dramatically [54] and also destroys the predicted enhancer. Modulation of GnRH expression mediated by Oct-1 has been shown in Gt1 cells, though the motif of importance is located upstream of the putative enhancer [39]. CREB has also been experimentally shown to induce human GnRH-II and to a lesser degree GnRH-I expression, in human neuronal cells [49]. Expression vectors were constructed using information from the TF binding site predictions. Expression from the vectors was confirmed by in vivo transient expression assays and by the formation of stable transgenic zebrafish lines harboring the full-length zebrafish or human GnRH promoters, fused to GFP and RFP respectively. The transgenic lines made it possible to study discrepancies between transgenic and transient expression data with respect to cell specificity between the zebrafish and human GnRH promoter driven reporter genes. The $\mathrm{p} \Delta(\mathrm{A} 24)$-GFP and $\mathrm{p} \Delta(\mathrm{A} 42)-$ GFP were unable to express, presumably due to the lack of the Oct-1, CREB and Sp1 motifs between -976 and -929 . The second CREB binding site at -878 present in $\mathrm{p} \Delta$ (A42)GFP is proposed to be non-functional. Expression from $\mathrm{p} \Delta$ (A33)-GFP, was as strongly tissue specific as was observed with the full-length promoter, confirming our in silico predictions, since the difference between the $\mathrm{p} \Delta$ (A33)-GFP and $\mathrm{p} \Delta$ (A42)-GFP constructs corresponds to the predicted enhancer. From this we conclude that this region featuring the putative Oct-1, CREB and Sp1 sites, is necessary for cell specific expression of the gnrh3 gene in zebrafish, hence supporting our TF binding site predictions. The $\mathrm{p} \Delta(\mathrm{A} 25)$-GFP construct featuring deletion of the CREB and Sp1 binding sites, was tested for influence upon expression. Forebrain expression was observed, but with a broader cell specificity shown by lack of co-localization with the full-length zebrafish RFP construct, and GFP activity observed in midbrain and hindbrain neuronal cells. This denotes that the Oct-1, CREB and possibly Sp1 are necessary for full cell specificity, because the Oct1 but not the CREB and Sp1 binding sites were retained in the deletion. Interaction between neighboring Oct-1 and CREB is to our knowledge not known in other promoters. Transgenic (F1) expression of the full-length GFP was observed in a number of cells located in the same area as that of transient expression, but the density of cells made visualizing GFP activity in the axons using fluorescence microscopy difficult. Confocal laser scanning microscopy confirmed the morphological similarities (data not shown), hence the same cell population express transiently and transgenically. Localization of the human driven RFP and zebrafish GFP to the same population of cells as also described for the Atlantic salmon GnRH-III promoter [62], show that the transcriptional machinery in zebrafish is capable of recognizing a human promoter and directing the tissue specific expression. These results confirm the hypothesis that teleost GnRH-III genes are orthologues of GnRH-I. Cells producing the releasing GnRH form originate from the olfactory placode and migrate to their final positions during brain development [63-68], though we made no attempts to investigate such events. Future experiments applying laser confocal microscopy of developing multi-transgenic zebrafish with alternative GnRH-I and GnRH-III, as well as GnRH receptor and GtH promoter constructs should be conducted to further investigate on- 
togeny, tissue specificity and regulatory mechanisms of $\mathrm{GnRH}$ and other genes involved in the HPG axis.

\section{Methods \\ Cloning of zebrafish gnrh3 RACE products}

Poly A selected RNA was isolated from frozen adult zebrafish brains, using an mRNA direct Kit (Dynal, Oslo, Norway). Primer sequences for 5' and 3' RACE reactions were selected from the conserved decapeptide and 5' GAP regions between goldfish (Carassius auratus) [69] and Atlantic salmon GnRH-III [29], and the resulting 5' RACE sequences, respectively. All primer-binding sites are shown schematically in fig. 4. Both 5' and 3' RACE reactions were conducted with a Boehringer Manheim 5'/ 3' RACE kit (Roche Diagnostics, Mannheim, Germany), using $1 \mu \mathrm{g}$ poly A RNA. Primer P1 (5'gcctccasytcmccwacacttctctt3') was used for synthesis of 5' RACE CDNA, and P2 (5'ggwagccraccgtaygaccagtgct3') plus an Oligo $\mathrm{d}(\mathrm{T})_{18}$ anchor primer for the 5' RACE PCR. A -21M13 tailed Oligo $\mathrm{d}(\mathrm{T})_{18}$ primer was applied for 3' RACE cDNA synthesis and a $-21 \mathrm{M} 13$ anchor primer plus P4 (5'gcatggagtggaaaggaaggtt3') in the 3' RACE PCR. All RACE PCR reactions were carried out with $0.1 \mu \mathrm{M}$ primers, $1.5 \mathrm{mM} \mathrm{MgCl} 2$ and 1 unit of Amplitaq polymerase (Applied Biosystems, Foster City, USA). The PCR cycling parameters were as follows: 1) 1 cycle of 10 min denaturation at $\left.95^{\circ} \mathrm{C}, 2\right) 35$ cycles with $20 \mathrm{sec} 95^{\circ} \mathrm{C}$ denaturation, $30 \mathrm{sec} 55^{\circ} \mathrm{C}$ primer annealing and $40 \mathrm{sec} 72^{\circ} \mathrm{C}$ extension and 3) 7 min extension at $72^{\circ} \mathrm{C}$.

\section{PCR amplification}

Genomic zebrafish DNA was isolated as described in the zebrafish book [70], with two additional chloroform extractions. PCR amplifications of intron 1 and 3 were performed with $0.1 \mu \mathrm{M}$ primer P5 (5' tcttgaacaaacacagca3') plus P6 (5'cacaaactaacagcaacaa3') and P7 (5'ctgtctattcctgctgatt3') plus P8 (5'ctcatatcagcttcatcat3'), respectively. The reactions were carried out with Amplitaq Gold (Applied Biosystems), $2.0 \mathrm{mM} \mathrm{MgCl}_{2}$ and $10 \mathrm{ng}$ genomic DNA: 1) $10 \mathrm{~min}$ at $95^{\circ} \mathrm{C}$, 2) 40 cycles of $60 \mathrm{sec}$ at $94^{\circ} \mathrm{C}, 60 \mathrm{sec}$ at $57,5^{\circ} \mathrm{C}$ and $90 \mathrm{sec}$ at $72^{\circ} \mathrm{C}$ and 3) $7 \mathrm{~min}$ at $72^{\circ} \mathrm{C}$. Intron 2 primary PCR was carried out with 20 ng genomic DNA, 1.5 to $3.5 \mathrm{mM} \mathrm{MgCl}_{2}, 1.0$ unit Hot Star polymerase (Qiagen, Hilden, Germany), and $0.4 \mu \mathrm{M} 5$ 'biotinylated

P92

(5'agcatggagtggaaaggaaggttgctggtccagtt3') and P93 (5'gcaaaccttcagcatccacctcattcacctgtaa3'). PCR conditions: 1) $95^{\circ} \mathrm{C}$ for $\left.15 \mathrm{~min}, 2\right) 40$ cycles of $94^{\circ} \mathrm{C}$ for $20 \mathrm{sec}$ and 90 sec at $72^{\circ} \mathrm{C}$ and 3 ) a $10 \mathrm{~min} 72^{\circ} \mathrm{C}$ step. The PCR reaction products were pooled and purified with a Dynapure ${ }^{\mathrm{TM}}$ Dye Terminator Removal Kit (Dynal). A secondary PCR was conducted with P94 (5'aacacacttacaaattaggctgccaatgtttt3') and P95 (5'gctgttagtttgtgtgttggaggtcagtcttt 3 '), using purified primary PCR products as template: 1) $95^{\circ} \mathrm{C}$ for 15 min, 2) 9 cycles of $94^{\circ} \mathrm{C}$ for $20 \mathrm{sec}$, annealing / extension touchdown from $72^{\circ} \mathrm{C}$ to $68^{\circ} \mathrm{C}$ for $90 \mathrm{sec}$, 3) 35 cycles of $94^{\circ} \mathrm{C}$ for $20 \mathrm{sec}$, and $72^{\circ} \mathrm{C}$ for $90 \mathrm{sec}$ and 4) $10 \mathrm{~min}$ at $72^{\circ} \mathrm{C}$. The human GnRH-I promoter was amplified from genomic DNA extracted from a $1 \mathrm{ml}$ blood-sample, using a Wizard genomic purification kit (Promega, Wisconsin, USA). A 1762 bp long promoter fragment [36], including $97 \mathrm{bp}$ of exon I [71], was amplified using $0.1 \mu \mathrm{M}$ of the PCR primers P122 (5'actagtctacccagagataagtgattcacctga3') and P123 (5'accggtctgtgacttttctgttttcctatcttcct3'), $200 \mathrm{ng}$ DNA, $1 \times$ Q-solution and 1.0 unit of Hot Star polymerase: 1) $15 \mathrm{~min}$ at $\left.95^{\circ} \mathrm{C}, 2\right) 35$ cycles of $94^{\circ} \mathrm{C}$ for $15 \mathrm{sec}, 55^{\circ} \mathrm{C}$ for $15 \mathrm{sec}, 2 \mathrm{~min}$. at $72^{\circ} \mathrm{C}$ and 3) $10 \mathrm{~min}$ at $72^{\circ} \mathrm{C}$.

\section{PCR promoter capture}

The zebrafish gnrh3 promoter was amplified by a PCR promoter capture method (Fig. 3), comprising two PCR reactions. Genomic zebrafish DNA was sheared by sonication and size fractionated in a 10 to $40 \%$ stepwise (5\% steps) sucrose gradient ultra centrifugation, for $18 \mathrm{hrs}$ at $28.000 \mathrm{rpm}$. Fractions of DNA were collected from the bottom of the tube, through a pierced opening (23 G needle), and analyzed on $0.8 \%$ agarose gel-electrophoresis. Asymmetrical PCR reactions were performed in $50 \mu \mathrm{l}$, with 1 unit Hot Star polymerase, $200 \mu \mathrm{M}$ dNTP, 400 ng 4$10 \mathrm{~Kb}$ DNA, 1.5 to $3.0 \mathrm{mM} \mathrm{MgCl}_{2}$ and $20 \mathrm{nM}$ of the biotinylated primer P74 (5'cttgctgacaaaacccacagcaat3'): 1) 15 min at $95^{\circ} \mathrm{C}$, 2) 40 cycles of $15 \mathrm{sec}$ at $94^{\circ} \mathrm{C}$ and $2 \mathrm{~min}$ of at $72^{\circ} \mathrm{C}$ and 3) $10 \mathrm{~min}$ at $72{ }^{\circ} \mathrm{C}$. The PCR reaction products were pooled and centrifuged in an Amicon Centricon YM-100 Mw centrifugal filter (Millipore, Bedford, USA), to remove excess of biotinylated primer. The asymmetrical PCR products were coupled to streptavidin coated Dynabeads and purified with Dynapure ${ }^{\mathrm{TM}}$ Dye Terminator Removal Kit (Dynal). Equal volume of binding buffer was gently mixed with the pooled PCR products and incubated for $5 \mathrm{~min}$ at room temperature. The suspension was washed twice with $150 \mu \mathrm{l}$ TE $\mathrm{pH}$ 8.0, once with $150 \mu \mathrm{l}$ $\mathrm{dH}_{2} \mathrm{O}$ and once with $50 \mu \mathrm{l} 1 \mathrm{X}$ Terminal Transferase buffer. The supernatant was discarded and the purified PCR products were poly adenylated in $20 \mu \mathrm{l} 1 \mathrm{X}$ terminal transferase buffer with $0.25 \mathrm{mM}$ fresh dATP and 20 units of terminal transferase (Promega) for $1 \mathrm{hr}$ at $37^{\circ} \mathrm{C}$. The polyadenylated PCR products were washed as described above, using $1 \mathrm{X}$ PCR buffer in the last step. Secondary nested PCR reactions were carried out with 1.5 to $3.0 \mathrm{mM}$ $\mathrm{MgCl}_{2}$ and Hot Star Taq polymerase, using $0.4 \mu \mathrm{M}$ of the primers P75 (5'gggctcgagagt $\left.{ }_{20} \mathrm{~b}^{\mathrm{b}}{ }^{\prime}\right)$ and P76 ( 5 'tgaacatttctatcacact3') in $25 \mu \mathrm{l}$ reactions. The PCR cycling was performed with; 1) 15 min denaturation at $\left.95^{\circ} \mathrm{C}, 2\right) 40$ cycles of $20 \mathrm{sec}$ at $94^{\circ} \mathrm{C}, 10 \mathrm{sec}$ at $55^{\circ} \mathrm{C}$ and 2 min at $72^{\circ} \mathrm{C}$, and 3 ) a $10 \mathrm{~min}$ at $72^{\circ} \mathrm{C}$. The PCR fragments were analyzed on $2 \%$ agarose gel electrophoresis, excised and purified prior to cloning and sequencing. A $1656 \mathrm{bp}$ promoter fragment was PCR amplified with the primers A25 (5'ggatcccttcagggatgccaggtctt3') and A26 
(5'ctcgaggctgtgtttgttcaagatgagttct3'), specific for the sequence obtained from the PCR promoter capture reactions. The PCR reaction was conducted with Hot Star polymerase, $100 \mathrm{ng}$ genomic DNA and $2.0 \mathrm{mM} \mathrm{MgCl}_{2}$. Cycling conditions: 1) $15 \mathrm{~min}$ at $\left.95^{\circ} \mathrm{C}, 2\right) 40$ cycles of 15 sec at $94^{\circ} \mathrm{C}, 10 \mathrm{sec}$ at $60^{\circ} \mathrm{C}$ and $2 \mathrm{~min}$ at $72^{\circ} \mathrm{C}$, and 3) 10 $\min$ at $72^{\circ} \mathrm{C}$.

\section{Sequencing}

All PCR products were cloned using the pGEM T-easy vectors (Promega) and sequenced either with vector or sequence specific primers. All sequencing reactions were carried out in $10 \mu \mathrm{l}$ reactions with Big Dye Terminator chemistry (Applied Biosystems) and analyzed on an ABI 377 automated sequencer (Applied Biosystems). The zebrafish gnrh 3 cDNA and gene have Gene Bank accession number AJ304429 and AF490354.

\section{Bioinformatics}

Contig assembly of the zebrafish sequences was conducted with Contig Express (Informax, Bethesda, USA) and the ORF was translated and analyzed using BLAST [72], with BLOSUM 62. The zebrafish gnrh3 promoter sequence was analyzed for presence of repeat regions and transposable elements, using Repeat Masker (Smit AFA, Green P [http://repeatmasker.genome.washington.edu/cgi-bin/ RepeatMasker]). Confirmation of Pol II promoter and recognition of the transcriptional start site was conducted with Promoter Scan II [73] and Neural Network Promoter Prediction (Reese MG, Harris NL, Eeckam FH [http:// www.fruitfly.org/seq_tools/promoter.html]). In silico analysis for transcription factor-binding sites was initiated with a search for TF's present in brain and neuronal cells, using TESS filtered search (Schug J, Overton CG [http:// www.cbil.upenn.edu/tess/index.html]). Secondly, a binding site analysis was conducted to find binding sites common to and missing from brain and gonad specific promoters respectively. To increase the reliability of these predictions, TESS filtered search, AliBaba 2.1 [57] and Matinspector professional [58] were compared and stringency optimized for correct prediction of the ERE described in the salmon Pa GnRH-III promoter [34]. In addition to the zebrafish gnrh3 promoter, the Atlantic salmon GnRH-III Pa and Pb [29], human GnRH-I upstream (II) [35] and downstream (I) [36], striped bass GnRH-I [37], rat GnRH-I [38], and African cichlid GnRHI and GnRH-III [22] promoters were analyzed for TF binding sites.

\section{Reporter gene constructs and microinjection}

The zebrafish $(-1656$ to +16$)$ and human $(-1762$ to +97$)$ GnRH promoter fragments were cloned into pGEM T-easy vectors prior to endonuclease digestion with Bam $\mathrm{HI} / \mathrm{Xho}$ I and Spe I / Age I, respectively. The promoter fragments were ligated into promoter-less hrGFP (Stratagene, La Jol- la, USA) and non-humanized pDsRed (Clontech, Palo Alto, USA) vectors, respectively. A full-length RFP version of the zebrafish construct was also made. A total of $4 \mathrm{ze}$ brafish GnRH promoter deletion constructs were created, using information from the TF binding site predictions. All PCR fragments for the promoter deletion constructs were fused to an hrGFP vector and named according to the sense primer used (Fig. 4b). Briefly, the PCR reactions were run with the primers listed in figure $4 \mathrm{~b}$ legend, Hot Star polymerase and $2 \mathrm{mM} \mathrm{MgCl} 2$. The cycling conditions were as follows; 1) $95^{\circ} \mathrm{C}$ for $\left.15 \mathrm{~min}, 2\right) 3$ cycles of $94^{\circ} \mathrm{C}$ for $15 \mathrm{sec}, 54^{\circ} \mathrm{C}$ for $15 \mathrm{sec}$ and $72^{\circ} \mathrm{C}$ for $\left.30 \mathrm{sec}, 3\right) 36$ cycles of $94^{\circ} \mathrm{C}$ for $15 \mathrm{sec}, 64^{\circ} \mathrm{C}$ for $15 \mathrm{sec}$ and $72^{\circ} \mathrm{C}$ for $30 \mathrm{sec}$, and 4) $5 \mathrm{~min}$ at $72^{\circ} \mathrm{C}$. All PCR products were ligated into pGEM T-easy vectors and digested with their corresponding restriction endonucleases (Fig. 4b), before fusion with the hrGFP vector backbone. The $\mathrm{p} \Delta$ (A25)-GFP vector was created by fusing two PCR products, creating a 91 bp deletion within the full-length promoter (Fig. 4b). Transgenic zebrafish were created by microinjection of $10^{6}$ copies of full-length zebrafish and human constructs into embryos at the one or two cells stage [74]. Transient and transgenic reporter gene expression was monitored with respect to onset and cell specificity of expression, from 24 hrs to 10 days post fertilization, using an Olympus BX 60 microscope (Olympus, Tokyo, Japan) equipped with NIBA and WG filter sets (Olympus). Fluorescence image capture and image processing was conducted with a Colourview-12 digital camera and Analysis Auto 3.1 software (Soft Imaging System, Münster, Germany).

\section{Authors' contributions}

Author 1, Torgersen, J., was involved in design of the study, cloning of cDNA, gene and promoter, vector construction, in silico analysis, fluorescence microscopy and preparation of the manuscript. Author 2, Nourizadeh-Lillabadi, R., participated in cloning of gene and promoter, and vector construction. Author 3, Husebye, H., participated in cloning of cDNA and gene, and preparation of the manuscript. Author 4, Aleström, P., was involved in experimental design, coordination and drafting of the manuscript.

\section{Acknowledgments}

We are grateful to Dr. Philippe Collas for fruitful scientific discussions, MeiRong Liang, Amilcar Arenal, Qirong Huang and Ingvild Berg are thanked for skillful technical assistance. Part of the work was funded through EU Grant BIO4-CT97-0554, EU Biotechnology Program, Project Assessment of biological containment and gene flow in transgenically sterile fish. J. Torgersen had Ph.D. scholarship funded through NRC Grant NRC 1211 07/I I 2, NRC Biotechnology Program, Project: MHC promoters for directing expression of antigens to be presented to the immune system of fish.

\section{References}

I. Sherwood N: Evolution of a neuropeptide family, Gonadotropin-releasing hormone. Amer Zool 1986, I04I-1054

2. Seeburg PH, Mason AJ, Stewart TA, Nikolics K: The mammalian GnRH gene and its pivotal role in reproduction. Recent Prog Horm Res 1987, 43:69-98 
3. King JA, Millar RP: Gonadotropin-Releasing hormones. In: Vertebrate Endocrinology: Fundamental and Biomedical Implications (Edited by: Pang PKT, Schreibman MP) Orlando, Academic Press 1991, I-33

4. Amano M, Oka Y, Aida K, Okumoto N, Kawashima S, Hasegawa Y: Immunocytochemical demonstration of salmon GnRH and chicken GnRH-II in the brain of masu salmon, Oncorhynchus masou. I Comp Neurol 1991, 3 I 4:587-597

5. Bailhache T, Arazam A, Klungland H, Alestrom P, Breton B, Jego P: Localization of salmon gonadotropin-releasing hormone mRNA and peptide in the brain of Atlantic salmon and rainbow trout. J Comp Neurol 1994, 347:444-454

6. Kah O, Breton B, Dulka JG, Nunez-Rodriguez J, Peter RE, Corrigan A, Rivier JE, Vale WW: A reinvestigation of the Gn-RH (gonadotrophin-releasing hormone) systems in the goldfish brain using antibodies to salmon Gn-RH. Cell Tissue Res 1986, 244:327-337

7. Radovick S, Wray S, Muglia L, Westphal H, Olsen B, Smith E, Patriquin $E$, Wondisford FE: Steroid hormone regulation and tissue-specific expression of the human GnRH gene in cell culture and transgenic animals. Horm Behav 1994, 28:520-529

8. Caraty A, Skinner DC: Dynamics of steroid regulation of GnRH secretion during the oestrus cycle of the ewe. Ann Endocrinol (Paris) 1999, 60:68-78

9. Habibi HR, Huggard DL: Testosterone regulation of gonadotropin production in goldfish. Comp Biochem Physiol C Pharmacol Toxicol Endocrinol 1998, 119:339-344

10. Dubois EA, Slob S, Zandbergen MA, Peute J, Goos HJ: Gonadal steroids and the maturation of the species-specific gonadotropin-releasing hormone system in brain and pituitary of the male African catfish (Clarias gariepinus). Comp Biochem Physiol B Biochem Mol Biol 200I, 129:381-387

II. Schreibman MP, Margolis-Nunno H, Halpern-Sebold LR, Goos HJ, Perlman PW: The influence of androgen administration on the structure and function of the brain-pituitary-gonad axis of sexually immature platyfish, Xiphophorus maculatus. Cell Tissue Res 1986, 245:519-524

12. Goos HJ, De Leeuw R, Cook H, van Oordt PG: Gonadotropic hormone-releasing hormone (GnRH) bioactivity in the brain of the immature rainbow trout, Salmo gairdneri : the effect of testosterone. Gen Comp Endocrinol 1986, 64:80-84

13. Montaner AD, Park MK, Fischer WH, Craig AG, Chang JP, Somoza GM, Rivier JE, Sherwood NM: Primary structure of a novel gonadotropin-releasing hormone in the brain of a teleost, Pejerrey. Endocrinology 200I, I 42: I 453-1460

14. Yoo MS, Kang HM, Choi HS, Kim JW, Troskie BE, Millar RP, Kwon HB: Molecular cloning, distribution and pharmacological characterization of a novel gonadotropin-releasing hormone ([Trp8] GnRH) in frog brain. Mol Cell Endocrinol 2000, I64:197204

15. Iwakoshi E, Takuwa-Kuroda K, Fujisawa Y, Hisada M, Ukena K, Tsutsui $\mathrm{K}$, Minakata $\mathrm{H}$ : Isolation and characterization of a $\mathbf{G n R H}-$ like peptide from Octopus vulgaris. Biochem Biophys Res Commun 2002, 29I: I I87-I I93

16. White RB, Eisen JA, Kasten TL, Fernald RD: Second gene for gonadotropin-releasing hormone in humans. Proc Natl Acad Sci USA 1998, 95:305-309

17. Yu KL, Sherwood NM, Peter RE: Differential distribution of two molecular forms of gonadotropin-releasing hormone in discrete brain areas of goldfish (Carassius auratus). Peptides 1988, 9:625-630

18. Lepretre E, Anglade I, Williot P, Vandesande F, Tramu G, Kah O: Comparative distribution of mammalian GnRH (gonadotrophin-releasing hormone) and chicken GnRH-II in the brain of the immature Siberian sturgeon (Acipenser baeri). J Comp Neurol 1993, 337:568-583

19. Montero M, Vidal B, King JA, Tramu G, Vandesande F, Dufour S, Kah O: Immunocytochemical localization of mammalian GnRH (gonadotropin-releasing hormone) and chicken GnRH-II in the brain of the European silver eel (Anguilla anguilla L.). J Chem Neuroanat 1994, 7:227-24I

20. Powell JF, Zohar Y, Elizur A, Park M, Fischer WH, Craig AG, Rivier JE, Lovejoy DA, Sherwood NM: Three forms of gonadotropin-releasing hormone characterized from brains of one species. Proc Natl Acad Sci U S A 1994, 9 I: : 208 I - I 2085

21. White SA, Kasten TL, Bond CT, Adelman JP, Fernald RD: Three gonadotropin-releasing hormone genes in one organism sug- gest novel roles for an ancient peptide. Proc Natl Acad Sci U S A 1995, 92:8363-8367

22. White RB, Fernald RD: Genomic structure and expression sites of three gonadotropin-releasing hormone genes in one species. Gen Comp Endocrinol 1998, II 2: 17-25

23. Carolsfeld J, Powell JF, Park M, Fischer WH, Craig AG, Chang JP, Rivier JE, Sherwood NM: Primary structure and function of three gonadotropin-releasing hormones, including a novel form, from an ancient teleost, herring. Endocrinology 2000, |4 1:505512

24. Gonzalez-Martinez D, Madigou T, Zmora N, Anglade I, Zanuy S, Zohar Y, Elizur A, Munoz-Cueto JA, Kah O: Differential expression of three different prepro-GnRH (gonadotrophin-releasing hormone) messengers in the brain of the european sea bass (Dicentrarchus labrax). J Comp Neurol 200I, 429:I44-I 55

25. Davis MR, Fernald RD: Social control of neuronal soma size. J Neurobiol 1990, 21:1 I80-1 I88

26. Powell JF, Fischer WH, Park M, Craig AG, Rivier JE, White SA, Francis $R C$, Fernald RD, Licht $P$, Warby C: Primary structure of solitary form of gonadotropin-releasing hormone (GnRH) in cichlid pituitary; three forms of $\mathrm{GnRH}$ in brain of cichlid and pumpkinseed fish. Regul Pept 1995, 57:43-53

27. White RB, Fernald RD: Ontogeny of gonadotropin-releasing hormone (GnRH) gene expression reveals a distinct origin for GnRH-containing neurons in the midbrain. Gen Comp Endocrinol 1998, II 2:322-329

28. King JA, Millar RP: Evolutionary aspects of gonadotropin-releasing hormone and its receptor. Cell Mol Neurobiol 1995, 15:523

29. Klungland $\mathrm{H}$, Lorens JB, Andersen $\mathrm{O}$, Kisen GO, Alestrom P: The Atlantic salmon prepro-gonadotropin releasing hormone gene and mRNA. Mol Cell Endocrinol 1992, 84:167-174

30. Powell JF, Krueckl SL, Collins PM, Sherwood NM: Molecular forms of GnRH in three model fishes: rockfish, medaka and zebrafish. J Endocrinol 1996, I 50:17-23

31. Penlington MC, Williams MA, Sumpter JP, Rand-Weaver M, Hoole D, Arme C: Isolation and characterisation of mRNA encoding the salmon- and chicken-II type gonadotrophin-releasing hormones in the teleost fish Rutilus rutilus (Cyprinidae). I Mol Endocrinol 1997, 19:337-346

32. Izsvak Z, Ivics Z, Garcia-Estefania D, Fahrenkrug SC, Hackett PB: DANA elements: a family of composite, tRNA-derived short interspersed DNA elements associated with mutational activities in zebrafish (Danio rerio). Proc Natl Acad Sci USA 1996, 93: $1077-108 \mid$

33. Koga $\mathrm{A}$, Hori $\mathrm{H}$ : Homogeneity in the structure of the medaka fish transposable element Tol2. Genet Res 1999, 73:7-14

34. Klungland $\mathrm{H}$, Andersen $\mathrm{O}$, Kisen $\mathrm{G}$, Alestrom $\mathrm{P}$, Tora L: Estrogen receptor binds to the salmon $\mathrm{GnRH}$ gene in a region with long palindromic sequences. Mol Cell Endocrinol I993, 95: I 47-I 54

35. Dong KW, Yu KL, Roberts JL: Identification of a major upstream transcription start site for the human progonadotropin-releasing hormone gene used in reproductive tissues and cell lines. Mol Endocrinol 1993, 7:1654-1666

36. Kepa JK, Spaulding AJ, Jacobsen BM, Fang Z, Xiong X, Radovick S, Wierman ME: Structure of the distal human gonadotropin releasing hormone (hGnrh) gene promoter and functional analysis in GtI-7 neuronal cells. Nucleic Acids Res 1996, 24:36|4-3620

37. Chow MM, Kight KE, Gothilf Y, Alok D, Stubblefield J, Zohar Y: Multiple GnRHs present in a teleost species are encoded by separate genes: analysis of the sbGnRH and cGnRH-II genes from the striped bass, Morone saxatilis. J Mol Endocrinol 1998, 21:277-289

38. Kepa JK, Wang C, Neeley Cl, Raynolds MV, Gordon DF, Wood WM Wierman ME: Structure of the rat gonadotropin releasing hormone ( $r G n R H)$ gene promoter and functional analysis in hypothalamic cells. Nucleic Acids Res 1992, 20:1393-1399

39. Clark ME, Mellon PL: The POU homeodomain transcription factor Oct-I is essential for activity of the gonadotropin-releasing hormone neuron-specific enhancer. Mol Cell Biol 1995 , 15:6169-6177

40. Wierman ME, Xiong X, Kepa JK, Spaulding AJ, Jacobsen BM, Fang Z, Nilaver G, Ojeda SR: Repression of gonadotropin-releasing hormone promoter activity by the POU homeodomain transcription factor SCIP/Oct-6/Tst-I: a regulatory mechanism of phenotype expression? Mol Cell Biol 1997, 17:1652-1665 
4I. Radovick S, Ticknor CM, Nakayama Y, Notides AC, Rahman A, Weintraub BD, Cutler GB Jr, Wondisford FE: Evidence for direct estrogen regulation of the human gonadotropin-releasing hormone gene. I Clin Invest I99I, 88:1649-1655

42. Dong KW, Chen ZG, Cheng KW, Yu KL: Evidence for estrogen receptor-mediated regulation of human gonadotropin-releasing hormone promoter activity in human placental cells. Mol Cell Endocrinol 1996, I I 7:24 I-246

43. Chen ZG, Yu KL, Zheng HM, Dong KW: Estrogen receptor-mediated repression of gonadotropin-releasing hormone (gnRH) promoter activity in transfected CHO-KI cells. Mol Cell Endocrinol 1999, I 58: |3|-| 42

44. Chandran UR, Attardi B, Friedman R, Dong KW, Roberts JL, DeFranco DB: Glucocorticoid receptor-mediated repression of gonadotropin-releasing hormone promoter activity in GTI hypothalamic cell lines. Endocrinology 1994, 134:|467-1474

45. Kepa JK, Jacobsen BM, Boen EA, Prendergast P, Edwards DP, Takimoto G, Wierman ME: Direct binding of progesterone receptor to nonconsensus DNA sequences represses rat $\mathbf{G n R H}$. Mol Cell Endocrinol 1996, II 7:27-39

46. Chappell PE, Levine JE: Stimulation of gonadotropin-releasing hormone surges by estrogen. I. Role of hypothalamic progesterone receptors. Endocrinology 2000, I 4 I: | 477- | 485

47. Lawson MA, Whyte DB, Mellon PL: GATA factors are essential for activity of the neuron-specific enhancer of the gonadotropin-releasing hormone gene. Mol Cell Biol 1996, 16:3596-3605

48. Lawson MA, Buhain AR, Jovenal JC, Mellon PL: Multiple factors interacting at the GATA sites of the gonadotropin-releasing hormone neuron-specific enhancer regulate gene expression. Mol Endocrinol 1998, I 2:364-377

49. Chen A, Laskar-Levy O, Ben Aroya N, Koch Y: Transcriptional regulation of the human GnRH II gene is mediated by a putative CAMP response element. Endocrinology 200I, I 42:34833492

50. Corley DR, Li X, Lei ZM, Rao CV: Potential regulation of GnRH gene by a steroidogenic factor-I-like protein. Mol Hum Reprod 2000, 6:67|-676

5I. Kelley CG, Lavorgna G, Clark ME, Boncinelli E, Mellon PL: The Otx2 homeoprotein regulates expression from the gonadotropinreleasing hormone proximal promoter. Mol Endocrinol 2000, I 4:1246-I 256

52. Coe IR, von Schalburg KR, Sherwood NM: Characterization of the Pacific salmon gonadotropin-releasing hormone gene, copy number and transcription start site. Mol Cell Endocrinol 1995, I I5:113-122

53. Higa M, Kitahashi T, Sasaki Y, Okada H, Ando H: Distinct promoter sequences of two precursor genes for salmon gonadotropinreleasing hormone in masu salmon. I Mol Endocrinol 1997, 19:|49-16|

54. Whyte DB, Lawson MA, Belsham DD, Eraly SA, Bond CT, Adelman JP, Mellon PL: A neuron-specific enhancer targets expression of the gonadotropin-releasing hormone gene to hypothalamic neurosecretory neurons. Mol Endocrinol 1995, 9:467-477

55. Suzuki K, Gamble RL, Sower SA: Multiple transcripts encoding lamprey gonadotropin-releasing hormone-I precursors. J Mol Endocrinol 2000, 24:365-376

56. Frech K, Quandt K, Werner T: Software for the analysis of DNA sequence elements of transcription. Comput Appl Biosci 1997, 13:89-97

57. Grabe N: AliBaba2: Context Specific Identification of Transcription Factor Binding Sites. In Silico Biol 2000, I:

58. Quandt K, Frech K, Karas H, Wingender E, Werner T: Matlnd and MatInspector: new fast and versatile tools for detection of consensus matches in nucleotide sequence data. Nucleic Acids Res 1995, 23:4878-4884

59. Frith MC, Hansen U, Weng Z: Detection of cis-element clusters in higher eukaryotic DNA. Bioinformatics 200I, 17:878-889

60. Klingenhoff A, Frech K, Quandt K, Werner T: Functional promoter modules can be detected by formal models independent of overall nucleotide sequence similarity. Bioinformatics 1999, I 5:180-186

61. Heinemeyer T, Chen X, Karas H, Kel AE, Kel OV, Liebich I, Meinhardt $T$, Reuter I, Schacherer F, Wingender E: Expanding the TRANSFAC database towards an expert system of regulatory molecular mechanisms. Nucleic Acids Res 1999, 27:318-322
62. Husebye $\mathrm{H}$, Collas $\mathrm{P}$, Alestrom $\mathrm{P}$ : A functional study of the salmon GnRH promoter. Mol Mar Biol Biotechnol 1997, 6:357-363

63. Muske LE: Evolution of gonadotropin-releasing hormone (GnRH) neuronal systems. Brain Behav Evol 1993, 42:2 I 5-230

64. Tobet SA, Sower SA, Schwarting GA: Gonadotropin-releasing hormone containing neurons and olfactory fibers during development: from lamprey to mammals. Brain Res Bull 1997, 44:479-486

65. Parhar IS, Iwata M, Pfaff DW, Schwanzel-Fukuda M: Embryonic development of gonadotropin-releasing hormone neurons in the sockeye salmon. J Comp Neurol 1995, 362:256-270

66. Francis RC, Lee HN, Fernald RD: Ontogeny of gonadotropin releasing hormone-containing neurons in the teleost brain. Brain Res Dev Brain Res 1994, 78:15I-160

67. Chiba $A$, Oka S, Honma Y: Ontogenetic development of gonadotropin-releasing hormone-like immunoreactive neurons in the brain of the chum salmon, Oncorhynchus keta. Neurosci Lett 1994, 178:5।-54

68. Amano M, Oka Y, Kitamura S, lkuta K, Aida K: Ontogenic development of salmon GnRH and chicken GnRH-II systems in the brain of masu salmon (Oncorhynchus masou). Cell Tissue Res 1998, 293:427-434

69. Lin XW, Peter RE: Expression of salmon gonadotropin-releasing hormone (GnRH) and chicken GnRH-Il precursor messenger ribonucleic acids in the brain and ovary of goldfish. Gen Comp Endocrinol 1996, 101:282-296

70. Westerfield M: The Zebrafish Book. A guide for the laboratory use of zebrafish Danio* (Brachydanio) rerio. Eugene 2000

7I. Hayflick JS, Adelman JP, Seeburg PH: The complete nucleotide sequence of the human gonadotropin-releasing hormone gene. Nucleic Acids Res 1989, 17:6403-6404

72. Altschul SF, Madden TL, Schaffer AA, Zhang J, Zhang Z, Miller W, Lipman DJ: Gapped BLAST and PSI-BLAST: a new generation of protein database search programs. Nucleic Acids Res 1997 25:3389-3402

73. Prestridge DS: Predicting Pol II promoter sequences using transcription factor binding sites. J Mol Biol 1995, 249:923-932

74. Collas $P$, Aleström $P$, Husebye $H$ : Transferring foreign genes into zebrafish eggs by microinjection. In: Transgenic animals - Generation and use (Edited by: Houdebine LM) Amsterdam, Harwood Academic Publ 1997, I19-122

Publish with BioMed Central and every scientist can read your work free of charge

"BioMedcentral will be the most significant development for disseminating the results of biomedical research in our lifetime." Paul Nurse, Director-General, Imperial Cancer Research Fund

Publish with BMC and your research papers will be:

- available free of charge to the entire biomedical community

- peer reviewed and published immediately upon acceptance

- cited in PubMed and archived on PubMed Central

- yours - you keep the copyright

Submit your manuscript here:

http://www.biomedcentral.com/manuscript/ 